\title{
Constituição da República Comunista do Brasil (década de 1930)'
}

\section{PROJETO DE CONSTITUIÇÃO DA REPÚBLICA COMUNISTA DO BRASIL}

Art. I - Fica proclamada e instituída para os habitantes do Brasil a República Comunista sobre a base socialista da posse imediata. sem propriedade, da terra e de todos os seus bens pelas populações reunidas em comunas de habitação, consumo e produção.

Art. II - O território da atual República burguesa ficará dividida em tantas comunas urbanas e agrárias quantos forem os agrupamentos de interesses comuns da habitação, consumo e produção.

Art. III - Essas comunas se governarão por conselhos por elas mesmas organizados sob a forma que melhor convenha aos seus interesses locais.

Art. IV - As comunas afins e limítrofes poderão organizar conselhos conjuntos em que nao prevalecam os interesses de uma sobre os de outra.

Art. V - Esses conselhos têm por fim regular os interesses locais e organizar o intercâmbio de artigos ou gêneros necessários de consumo geral sobre a base da troca de valor convencional ou estabelecido.

1 Extraído de PENNA, Lincoln de Abreu. Caminhos da soberania nacional: os comunistas e a criação da Petrobras. Rio de Janeiro: E-papers, 2005, p. 177-182. 
Art. VI - As comunas poderão, se isso consultar o seu interesse ou sua segurança, organizar o tributo voluntário, com o fim de:

a) Enviar delegados ao Congresso Comunista Central.

b) Custear despesas para a aquisição de gêneros ou artigos não produzidos na República.

c) Assoldar voluntários e armá-los quando concordarem com a direção central da República na organização de exércitos revolucionários ou de defesa social.

d) Custear despesas com a criação de escolas, asilos, maternidades, hospitais, bibliotecas, jardins, estradas e quaisquer obras de caráter público e de uso comum.

Art. VII - As comunas poderão, se isso Ihes convier, agrupar-se, regionalmente, em estados que serão autônomos, sempre que a sua comuna urbana principal comporte um número maior de 50 mil habitantes e se limitam geograficamente por acidentes físicos definidos (cursos d'água, montanhas, florestas, desertos etc.).

Art. VIII - As comunas urbanas de menor população constituirão comarcas com autonomia municipal e direito de agrupamento, ou não, ao Estado limítrofe, nas organizações comunais.

Art. IX - As comunas urbanas menores ainda poderão organizar-se em municípios com direitos idênticos.

Art. X - Os estados unidos, não extintos, que aceitarem a forma comunista poderão federar-se a República desde que os habitantes declarem revolucionariamente:

a) A abolição do direito de propriedade.

Art. XI - A divisão territorial do Brasil em novos estados será regulada imediatamente, por uma congregação de competentes da Sociedade de Geografia do Rio de Janeiro, que é declarada de utilidade pública e requisitada para esse fim. 
Art. XII - A organização comunista da República assentará sobre as seguintes bases:

a) Comuna central do Rio de Janeiro, com um Conselho Central e delegados locais na proporção de um (I) por 20 mil habitantes da cidade e um (1) por 200 mil delegados de outros estados.

b) Comunas urbanas com conselhos estaduais de delegados na proporção de um (1) por cinco mil habitantes da cidade e um (1) por 50 mil habitantes das comunas estaduais circunvizinhas.

c) Comunas agrárias com conselhos de delegados locais, na proporção de um mil habitantes.

Art. XIII - As comunas agrárias elegerão delegados para os conseIhos urbanos, estes para os estaduais e estes para o central nas proporções que forem arbitradas pelas suas organizações sociais.

Art. XIV - O Conselho Central do Rio de Janeiro se comporá de tantos membros quantos forem os ramos de atividades sociais necessárias à República e provisoriamente será instituído pelos seguintes comissários do povo: Relações Exteriores, Relações Estaduais, Viação Terrestre, Navegação, Trabalho Industrial, Conciliação Social (cultos e expropriações), Exército, Armada, Trabalho Agrícola, Comércio, Finanças, Instrução e Inatividade Social.

Art. XV - Cada um dos comissários do povo exercerá, como Chanceler de atos públicos, durante um mês, a direção geral da República, e serão todos escolhidos por eleição pela Comuna Central dos delegados da República, por anos, sendo reelegíveis até por dois (2) anos consecutivos e demissíveis por deliberação de uma maioria de 23 votos do Conselho Central.

\section{Art. XVI - A REPÚBLICA DECLARA:}

a) A liberdade social, moral e econômica de todos os indivíduos nascidos ou residentes no País que tenham mais de 16 (dezesseis) anos de idade.

b) A igualdade social, moral e econômica dos dois sexos. 
c) A atividade necessária à comunidade de todos os indivíduos maiores de 16 (dezesseis) anos e menores de 50 (cinqüenta) anos;

d) A inatividade voluntária de todas as crianças, mulheres, velhos e enfermos do País.

e) A obrigação republicana de educação, proteção e assistência a todos, e compulsória à maternidade, à orfandade, à invalidez, à enfermidade, à demência e a criminalidade.

f) O reconhecimento da autoridade matriarcal sobre os filhos com ou não a colaboração da paternidade.

g) A liberdade das uniões sexuais.

h) A garantia dos agrupamentos voluntários em família.

i) O direito dos cultivadores às terras cultivadas, dos obreiros às fábricas, instrumentos e produções de seu trabalho, dos habitantes às casas que ocupem ou que lhes convenham.

Art. XVII - A REPÚBLICA DECIARA MAIS:

a) A socialização imediata de todos os produtos armazenados para consumo dos habitantes, fazendo como depósitos públicos todas as casas de negócios do País das quais serão requisitados os gêneros e artigos de que se necessite para uso imediato.

b) A abolição imediata de todas as dívidas públicas e particulares.

c) A expropriação imediata com a cessação consecutiva de direitos decorrentes de todas as propriedades privadas sobre casas e terras de fábricas e de minas, água e materiais de transporte.

d) A socialização das empresas de transporte, navegação, força e luz, dos bancos e companhias aéreas e portos, escolas, asilos, prisões e edifícios públicos, ficando todas essas instituições sob a direção dos sindicatos técnicos de seus empregados. 
e) A libertação imediata de todos os presos políticos e todos os crimes comuns de dois anos de detenção.

f) A organização de tribunais revolucionários deliberando por maioria, para julgamento de atentados contra a liberdade e a igualdade comunistas pela burguesia e seus adeptos.

Art. XVIII - A REPÚBLICA RECONHECE:

- Os conselhos de soldados e marinheiros, conjuntos ou separados, que deliberem sobre a segurança externa da República.

- Os conselhos de operários e camponeses que deliberem sobre a segurança interna da República.

- Os conselhos de mulheres para a organização da família.

- Os conselhos de letrados e intelectuais sobre questões de instruções e educação.

\section{Art. XIX - A REPÚBLICA NÃO RECONHECE:}

- As igrejas e confissões religiosas.

- O exército organizado por hierarquia e conscrição.

- A polícia e a justiça.

- A diplomacia e o funcionalismo.

- O jornalismo.

\section{Art. XX - A REPÚBLICA ORGANIZARÁ:}

- A propaganda revolucionária comunista, o Exército sobre pé de igualdade e reciprocidade de direitos e deveres entre comandantes e comandados.

- A guarda vermelha e seus tribunais revolucionários.

- A representação internacional. 
- Os empregados nacionais.

- A instrução social.

\section{DITADURA PROLETÁRIA}

Art. XXI - Fica instituída a Ditadura Proletária, por tempo indeterminado para a execução da presente constituição sobre as seguintes bases:

- Um Conselho Central Deliberativo constituído de tantos membros quantas as especialidades fabris ou manufatureiras e na proporção de $5 \%$ de cada fábrica de mais de 500 operários, $2 \%$ das mais de 50 e um de cada agrupamento isolado.

- $15 \%$ de soldados, sargentos e marinheiros proporcionalmente aos corpos e navios a que pertençam.

- $1 \%$ de oficiais até o segundo posto e aspirantes, desde que hajam destituído a oficialidade superior.

- $2 \%$ para empregados do comércio a varejo por bairros com exclusão de sócios e interessados.

- $10 \%$ de trabalhadores agrários de pequena lavoura proporcionalmente as deliberações tomadas por ele e terão atribuições:

a) Para organizar tribunais revolucionários;

b) Para comandar diretamente ou por delegação o Exército e a Guarda Vermelha;

c) Para regular a expropriação e seus efeitos preparatórios;

d) Para nomear delegados revolucionários nos estados e representantes no exterior;

e) Para desmonetizar a moeda existente e amoldar valores sob novos padrões; 
f) Para declarar de utilidade pública os institutos e instituições de Instrução, Higiene e Assistência e Educação e remodelá-los sob o regime comunista;

g) Para regular o modo de requisição e distribuição de alimentos, vestimentas e habitações populares;

h) Para nomeação dos primeiros comissários do povo e procedimento imediato de organização dos respectivos serviços republicanos;

i) Para submissão do Conselho Distrital Proletário dos Projetos de organização e dissoluções necessárias ao estabelecimento definitivo da remodelação no País.

Art. XXIII - A Bandeira da República Comunista terá as mesmas cores da atual, sendo substituída a esfera central por outra, com as inscrições em preto "PELO BRASIL COMUNISTA", em cima e embaixo "Pela REVOLUÇÃO INTERNACIONAL". O Hino Nacional Brasileiro será o da Internacional. 